\title{
Negotiations as a tool of business strategy creation
}

\section{Introduction}

In this paper, the problem of creating a company strategy within the strategic planning process is discussed. Instead of a traditional approach to solving this problem (thoroughly described in the literature on strategic management**), an alternative concept of company strategy elaboration is suggested. Namely, the author will try to prove that inter-organizational negotiations may be treated as a useful tool to be applied within the strategic planning process. Therefore, this paper aims to characterize such negotiations.

\section{The definition of negotiations as a strategy creation tool}

At first, let us assume that the parties of negotiations (as a tool of business strategy creation) are those organizational units in a company that are jointly responsible for developing the company's strategy, due to the functions they perform and/or the competencies they possess (decision-making and/or professional ones).

In order to present the concept of negotiations as a tool of business strategy creation, one should consider the following general definitions of negotiations, most frequently discussed in the literature (Lewicki et al. 2010; pp. 4-16, Kozina 2012; pp. 23-47, Thompson 2001; pp. 3-8).

* Cracow University of Economics, Faculty of Management, Management Process Department, e-mail: kozinaa@uek.krakow.pl.

** Due to limited size of the paper, the overview of basic notions and concepts of strategic management is not included. Those issues are thoroughly discussed in broad literature; e.g. Johnson et al. 2008 and Pearce and Robinson 2012. 
1. Negotiations as a process. This is the most general and common way of defining negotiations. Namely, they constitute a kind of project (venture) that is long-lasting (time-consuming) and very complex, including a number of sub-processes (phases, stages). Within them are numerous particular actions (implemented sequentially or cyclically) and the interactions between them. A strategy formulation itself constitutes such a specific and complex venture, so the negotiation process is supportive to that venture.

2. Negotiations as a method of conflict management; i.e., the way of resolving disputes that occur between the parties to these negotiations (organizational units), seeking to pursue their own goals and, simultaneously, to achieve the best results for a company, which is synthetically reflected in the adopted concept of its strategy (to as large of an extent as possible).

3. Negotiations as a method of achieving agreement. The basic premise for all negotiations (intra-organizational ones in particular) is striving to achieve synergistic benefits for all stakeholders (groups of interests); i.e., to develop an agreement that is much more favorable (profitable) to all of them than the lack of such agreement. In the discussed case, the strategy is a key determinant (reference point) to the search for integrative solutions by joint activities.

4. Negotiation as mutual dependence between their parties (expresses the close interaction between the two previous aspects). This means the co-existence of two dimensions: cooperation and competition, through the combination of conflicting and common objectives of the parties. This expresses their willingness to achieve an outcome that is favorable for both of them, supported by the need to resolve any conflicts that may occur. None of the participants in negotiations can achieve his/her goals independently, and at the same time, each of them can help the other parties achieve their goals. A relationship of this kind is an imminent feature of all activities in each organization, within the process of creating its strategy in particular.

5. Negotiations as an interactive decision-making process. At first, it is conducted by each negotiating party independently (according to his/her objectives) as a result of the analysis of a decision problem. Afterwards, the phase of reciprocal arrangements takes place, concerning both alternative solutions and the criteria for their evaluation, in order to develop a joint decision. In the discussed negotiations, the strategy becomes such a decision, or rather a set of many detailed decisions. Thus, the strategy is the result of the conciliation of the intentions and expectations (requirements or even demands) of various organizational units.

6. Negotiations as a communication process; namely, the mutual exchange of information accompanying all actions of the parties, from the initial presen- 
tation of their positions, through: establishing relationships between them, formulating and exchanging offers, convincing themselves, making deals, etc., until reaching a final agreement. Within the process of creating corporate strategy, a considerable number of such activities occurs.

7. Negotiation as a process of mutual exchange of two kinds of values: tangible and intangible (on the terms agreed by the parties). Such an exchange is carried out through mutual understanding and concessions. In the considered negotiations, it focuses on seeking the most favorable strategic options, reflecting a satisfactory level of productivity of resource utilization.

8. Negotiation as a process of value creation. The interdependence of the parties and reciprocal exchange in negotiations allow them to achieve mutual benefits by creating an additional value (synergistic effect) of both a material and non-material character, which would not be possible without negotiations. Therefore, a company's strategy is such new (added) value, enabling the formulation and accomplishment of key objectives of a company; i.e., the most important from the point of view of its survival and development.

In the context of the study (i.e., from the point of view of a company's needs), negotiation is treated as an instrument (tool) within the process of business management [Kozina 2012; pp. 48-49]. Such an understanding of the place and role of negotiations in a company obviously relates to the process of formulating its strategy; i.e., they are used as a specific method of strategic management (strategic analysis and planning processes in particular). Therefore, negotiation can be treated as a supplementary tool to typical, well-known methods applied in those processes, such as PESTEL, SWOT and competitive forces analyses, scenarios, benchmarking, portfolio techniques, value chain analysis, and so on (Johnson et al. 2008, Pearce and Robinson 2012).

\section{The features of negotiations as a strategy creation tool}

In order to explain the nature of negotiations as a strategy creation tool thoroughly enough, it is necessary to specify their most important features, resulting from either the specifics of the entire process of strategy formulation or the general classification of negotiations within a company.

As a starting point to identify the features of considered negotiations, the model created by Dwojacki (1995) may be applied (chosen among many other methodological concepts of strategy elaboration). In the frame of this model, four possible approaches to the creation and implementation of company strategy are distinguished. These approaches have been developed based on two dimensions: the degree of decision making centralization, and the extent of the formalization 
of the organizational structure of a company. Two levels of intensity of these dimensions are taken into consideration: low and high. The description of these four approaches is shown in Table 1. Obviously for the purpose of the study, the negotiating approach is most relevant, described in the bottom right element of Table 1 . However, this approach will be defined a bit differently than the original one introduced by P. Dwojacki (which will be explained at the end of present section of the paper).

Table 1

Four approaches to strategy development

\begin{tabular}{|c|l|l|}
\hline $\begin{array}{c}\text { Deci- } \\
\text { sions } \\
\text { cen- } \\
\text { trali- } \\
\text { zation }\end{array}$ & \multicolumn{1}{|c|}{ Formalization of organizational structure } \\
\cline { 2 - 4 } High & $\begin{array}{l}\text { Hlanning model - the process of } \\
\text { elaborating the strategy is not } \\
\text { performed by top management, } \\
\text { but by specialized organizational } \\
\text { units or project teams of special- } \\
\text { ists from different functional } \\
\text { areas. However, top manage- } \\
\text { ment is responsible for making } \\
\text { strategic decisions }\end{array}$ & $\begin{array}{l}\text { Lntrepreneurial model - little or no in- } \\
\text { volvement of employees in the strategic } \\
\text { planning process exists. Top manage- } \\
\text { ment prepares and develops a strategy } \\
\text { on its own, occasionally calls external } \\
\text { specialists for help. Therefore there is } \\
\text { no formal organizational procedures } \\
\text { relating to strategic planning, and } \\
\text { the only decision-maker is the top man- } \\
\text { agement of a company (or its owner) }\end{array}$ \\
\hline Low & $\begin{array}{l}\text { Participating model - the whole } \\
\text { process of preparing company's } \\
\text { strategy is initiated by top man- } \\
\text { agement (active role), however } \\
\text { other, different (formal and } \\
\text { or informal ones) groups of } \\
\text { employees actively participate to } \\
\text { this process, mainly by express- } \\
\text { ing opinions, which are respect- } \\
\text { ed by top management }\end{array}$ & $\begin{array}{l}\text { Negotiating model - it is assumed that } \\
\text { every employee, regardless of the posi- } \\
\text { tion occupied in organizational struc- } \\
\text { ture, may be the initiator of the process } \\
\text { of strategy development. This may re- } \\
\text { sult in the game for influence or forcing } \\
\text { one's own ideas. This model provides } \\
\text { broad participation of employees, } \\
\text { however does not guarantee reaching } \\
\text { consensus during strategy creation }\end{array}$ \\
\hline
\end{tabular}

Source: own elaboration based on Dwojacki 1995

Firstly, the most important feature of negotiations as a tool of business strategy creation is their nature (character). Namely, they are of intra-organizational character. Therefore, the principal partners (parties) of them are different internal stakeholders (or their representatives), although the participation of external groups of interests is also possible, such as experts (consultants), investors, sup- 
pliers, subcontractors, etc. In addition, some individuals or organizations from a company's eternal environment may be important, especially customers, suppliers, and competitors.

Secondly, to the considered negotiations participate the most important positions and organizational units of a company, which are:

- a company's management board, which plays a crucial role in those negotiations, since it is directly responsible for creating and implementing the company's strategy,

- owners and/or a supervisory board, as well as headquarters, which govern and control the activities of the management board,

- functional directors, like managing, sales and marketing, operations, personal, and financial, responsible for the contribution to creating both a general (global) strategy and functional (partial) strategies (policies) within their areas of activity,

- position (units) that are specialized in the field of analytical work necessary to support the process of strategic analysis and planning,

- heads of strategic business units, like profit and cost centers, branches, subsidiaries,

- organizational units performing tasks relevant to the functional strategies that express the overall strategic concept, such as marketing, sales, procurement, finance, human resource management, and other departments,

- other groups of interests, such as trade unions, informal groups exerting pressure on top management decisions, different associations, etc.

Thirdly, the negotiations conducted to create company strategy are of largely unique character and even unprecedented, possibly only partially routine ones. Therefore, one can use within them - as supporting tools - standard procedures, instructions, guidelines, etc., only to a limited extent; i.e., for solving particular problems. Such tools are usually elaborated within the formal framework of the strategic planning process.

Fourthly, the negotiations aimed at elaborating company strategy as a rule comprise a very wide range of issues (problems), practically covering all areas of company performance. They concern the matters reflecting to both internal and external circumstances, including opportunities (occasions) and threats (constraints) to company performance. They relate to the strategic concept itself, the determinants of its creation, and necessary conditions for its implementation as well as its concretization in the form of functional strategies and operational programs.

Finally, two basic types of the considered negotiations as a highly-complex venture may occur (be distinguished). 
Firstly, multiparty (multilateral) negotiations - including all or various combinations of the many potential parties listed above. Major features of such negotiations, compared to the attributes of bilateral ones, are as follows (Kamiński 2003; pp. 94-97).

1. Mutual dependences and relations - equivocal, heterogeneous, complicated, difficult to identify and analyze vs. unequivocal, homogeneous, simple and relatively easy to identify and analyze.

2. Terms (conditions) of a potential agreement - the acceptance of all sides is not always necessary and/or possible vs. reciprocal acceptance of both parties is required.

3. Negotiator behavior - considers too much broader and multidimensional context vs. mutual reactions to one's behaviors.

4. Nature of processes - highly complex vs. communication, exchange, and value creation processes within bilateral relations.

5. Potential negotiation strategies - a greater number of them vs. two basic strategies: cooperative and competitive (possibly their different mixtures and combinations)*.

Secondly, multiple negotiations, which are in fact a number of separate (individual, partial) negotiations, performed sequentially and/or in parallel by the management board with the other potential parties of the considered negotiations, concerning particular issues within their general scope. These negotiations are less complex than multiparty ones, but anyway require much effort of all employees involved as well as the effective coordination of their activities by managers at each level of the organizational hierarchy.

Summing up, it should be emphasized that the author's concept is similar to the "negotiating" approach proposed by Dwojacki (1995), characterized in Table 1 (its bottom right element), in the sense that both models assume a low level of decision centralization and treat negotiations as a leading tool of strategy creation. However, there is a substantial difference between those models; namely, the author's concept implies that the leading role in the process of strategy creation is played by top management, due to its crucial role in the overall process of developing and implementing a company's strategic management. Top management initiates, plans, organizes, supervises, and controls all of the activities within that process, using numerous instruments (including negotiations). Therefore, the author's concept is an intermediate solution (mixture) between approaches: "negotiating" and "participating", proposed by Dwojacki (1995), described in Table 1 (its bottom right and left elements).

* For detailed description of multiparty negotiations see the monograph Susskind and Crump 2008. 


\section{Negotiation strategies in the creation of company strategy}

Performing negotiations as a strategy creation tool requires the application of such tools that are adequate to their particular features. Especially, the selection of relevant strategy for their conduct is needed. Considering the two types of such negotiations (presented above), it seems to be appropriate to recommend the following two concepts of conducting such negotiations.

Firstly, taking into consideration the definition and features of multiparty negotiations (see the second section of the paper), the three fundamental criteria to classify their strategies may be used. Each of the criteria allows distinguishing two, thus all of them six; i.e., three pairs of basic (pure, single-dimensional) negotiation strategies, described below (Kozina 2007).

1. Including the general attitude towards negotiations (their parties, goals, mutual relations, and context), which is reflected in traditional concept of integrative versus distributive bargaining, two basic strategies may be distinguished; namely:

a) cooperative - the negotiator is focused on finding solutions which satisfy the interests of all parties, to reach common ground, and to look for potential allies,

b) competitive - the negotiator searches for solutions which satisfy only his interests and fights against his opponents.

2. Considering the negotiator's bargaining power, two pure strategies can be discriminated:

a) superiority (supremacy) - when the position of a particular negotiator against other parties is relatively strong, he dominates over others and has many possibilities,

b) inferiority (subordination) - reflecting a weak negotiator's position, subordinated to other parties, and having limited opportunities, which reflects the actual negotiator's possibility for controlling the negotiation process and scope of determining the activities of the other parties.

3. According to the possible ways of performing negotiations in relation to other parties within a group, two basic strategies can be pointed out:

a) individual - the negotiator acts solely on his own, but impacting indirectly his partners,

b) common - the negotiator is involved in teamwork, directly and substantially influencing group structure and processes.

The pure negotiation strategies listed above are not sufficient to reflect the complexity of multiparty negotiations. Therefore, it is necessary to combine 
the three classification criteria; i.e., look at those strategies from three-dimensional perspective, which leads to elaborating eight potential, resultant strategic options - see Table 2.

Table 2

Three-dimensional classification of multi-party negotiations

\begin{tabular}{|l|l|l|l|}
\hline \multicolumn{2}{|c|}{$\begin{array}{l}\text { Strategies (pure and } \\
\text { resultant) }\end{array}$} & \multicolumn{1}{c|}{ Individual } & \multicolumn{1}{c|}{ Collective } \\
\hline $\begin{array}{l}\text { Coopera- } \\
\text { tive }\end{array}$ & Superiority & $\begin{array}{l}\text { Entrepreneurial } \\
\text { [Creator] }\end{array}$ & $\begin{array}{l}\text { Integration (forming coalition) } \\
\text { [Integrator] }\end{array}$ \\
\cline { 2 - 5 } & Inferiority & $\begin{array}{l}\text { Encouragement } \\
\text { demonstration } \\
\text { [Supporter] }\end{array}$ & $\begin{array}{l}\text { Accession to coalition } \\
\text { [Nexus] }\end{array}$ \\
\hline $\begin{array}{l}\text { Competi- } \\
\text { tive }\end{array}$ & Superiority & $\begin{array}{l}\text { Fight } \\
\text { [Terminator] }\end{array}$ & $\begin{array}{l}\text { Disintegration (destroying coalition) } \\
\text { [Saboteur] }\end{array}$ \\
\cline { 2 - 4 } & Inferiority & $\begin{array}{l}\text { Opposition manifesto } \\
\text { [Don Quixote] }\end{array}$ & $\begin{array}{l}\text { Accession to adverse coalition } \\
\text { [Oppositionist] }\end{array}$ \\
\hline
\end{tabular}

Source: Kozina 2007

For each of the eight strategies, it is necessary to specify conditions for their effective implementation; i.e., identify and clarify all crucial factors that enhance the possibilities of the application of those strategies to particular negotiation situations (Kozina 2007).

Taking into account the fact that, by definition, each organization is designed to integrate different actors and groups of interests around the common objectives and activities (within the process of creating business strategy in particular), recommended strategies for the discussed negotiations are collective and cooperative ones. Therefore, it is appropriate to adopt one of the following two strategies:

1) Integration (forming a coalition) - by searching for high-quality agreements with other organizational units, a company's management board strives for joint problem solving and achieving objectives efficiently. Particularly, such a strategy is recommended when the company has considerable potential, which leads to gaining the best end results, entirely relevant to its key objectives.

2) Accession to coalition, used in the situations where for particular organizational unit the cooperation with other units constitutes the best (and sometimes only) way to improve its weak bargaining position, in order to accomplish (at least partially) its particular objectives. This can also contribute remarkably to the achievement of common organizational goals. 
It should be emphasized that both the general definition of negotiations (presented above) as well as the specific nature of an organization entail the occurrence of different kinds of conflicts within the discussed negotiations. That results mainly from the occurrence of divergent goals, individual and collective ones, performing different organizational roles, the need to allocate scarce resources, etc. Therefore, one can consider the use of other strategies (apart from the two recommended above) to conduct the discussed negotiations, even focused on fighting or disintegration of teams and activities. Therefore, a very important purpose of the management board is to manage such conflicts effectively, through the maximum utilization of their positive functions (i.e., motivating employees to seek creative solutions to arising problems).

Secondly, as far as multiple negotiations are concerned, it should be stressed that, like in multiparty negotiations, the preferred strategy is the cooperative one, focused on the search for integrative solutions. Thus, the task of the management board as a "key link" in the discussed negotiations is to pursue a collective strategy by creating conditions for cooperation, the integration of crucial stakeholders around common goals, coordinating the activities of all negotiating parties, and motivating and empowering employees. Just like in the previous case, it becomes necessary to efficiently resolve potential conflicts arising due to the interactions among individuals and organizational units.

In multiple negotiations, a very significant problem of coordination arises, which must be resolved by top management. This is the occurrence of the following types of links between numerous negotiation situations within a company (Watkins and Passow 1996).

1. Relationship between separate matters, including:

a) synergistic - combine the issues which could be negotiated separately in such a way that they form a potential additional benefit,

b) antagonistic - restricting the possibilities of agreement - not only some controversial issues cannot be resolved, but they also make it difficult to resolve the other ones.

2. Relationship in time, including two types:

a) sequential - occur when the previous (ongoing) negotiations have an impact on the subsequent (future) negotiations,

b) simultaneous - arise when the related negotiations coincide or overlap with one another; including:

- competitive - happen when one party is negotiating with two or more parties, and only one of these negotiations can result in an agreement,

- binaural - when one side is negotiating with two or more parties, and all of these negotiations must be successful in order to complete an entire project, 
- conditional - each agreement with one party depends on reaching an agreement with the other ones.

It is necessary to assess the significance of the considered links from the point of view of the expected degree of their influence on the course and results of particular negotiations. Priority should be given to those that determine the degree of the achievement of the objectives, then one should take care of minor issues (easier to solve), and finally - it is recommended to treat marginally (or even skip) the links of minimal importance, causing routine problems, mostly procedural ones.

With regard to the relationship between the separate issues when planning negotiations, one should take the following courses of action:

1) for synergistic links - identifying the opportunities and making efforts to increase the overall benefits by extending the possibility of agreement and strengthening the positive impact of one negotiation on the other ones as a source of potential benefits,

2) for antagonistic relationships - identifying threats (obstacles) and attempting to transform potential conflicts by reducing the existing disparities and to minimize the negative impact of one negotiation on the others, as causes of potential losses.

Taking into account the links among negotiations in time, the following are necessary:

1) for sequential links - taking into account the outcome of previous negotiations and/or potential implications for future negotiations,

2) for simultaneous links - coordinating ongoing negotiations at the same time.

\section{Evaluation of the proposed concept}

Summing up, on the one hand, the proposed concept of creating a business strategy through negotiations can be considered a useful managerial tool. It has the following advantages:

1) it facilitates the identification of various groups of interest within a company, their objectives, and potential of competencies,

2) it guarantees the involvement of many individuals and organizational units in the process of strategy formulation; thus, it facilitates its comprehension and acceptance as well as a thorough exploration of the possibilities and limitations of a company's performance,

3 ) it contributes to the effective integration around common goals, 
4) it also motivates employees to work collectively, which allows finding strategic options of better quality through the cooperation of the parties involved in the discussed negotiations,

5) it creates the conditions for the effective implementation of the selected strategy, particularly helping to minimize the natural resistance to change that usually occurs during such an implementation,

6) it makes it fairly easy to transform general company strategy into functional strategies, policies, and operational programs of detailed activities.

On the other hand, the proposed concept has some major drawbacks. First of all, in practice, it can be time consuming, since a considerable quantity of interaction among many parties involved in negotiations delay noticeably making final deals. There may also be coordination difficulties, particularly for large organizations, with a considerable degree of diversification, within which a prettywide differentiation of goals and interests exists. In addition, the pursuance of consensus or compromise (force by majority) can leave outside the scope of suggested solutions (strategic options) the needs, requirements, and expectations of certain groups or individuals (minorities). As a result, their goals and interests will not be adequately reflected in the strategy.

Within the frame of future research on the discussed concept, the stress will be put on its improvement. First of all, it will be necessary to clarify the features of the considered negotiations by specifying their dimensions and parameters. It will also be necessary to broaden the scope of study of their conditions. In addition, the search for new tools of the detailed description and in-depth analysis of the discussed negotiations is intended, including the tools of dual origin: from negotiation theory and management theory.

\section{References}

[1] Dwojacki, P. (1995) 'Organizacja planowania strategicznego - rola naczelnego kierownictwa' [Organization of Strategic Planning - the Role of Top Management], Przegląd Organizacji, nr 8, pp. 9-11.

[2] Johnson, G., Scholes, K. and Whittington, R. (2008) Exploring Corporate Strategy: Text and Cases, $8^{\text {th }}$ edition, London: Prentice Hall.

[3] Kamiński, J. (2003) Negocjowanie. Techniki rozwiązywania konfliktów [Negotiating. The Techniques of Conflicts Resolution], Warszawa: Poltext.

[4] Kozina, A. (2007) 'Strategie negocjacji wielostronnych' [Multiparty Negotiations Strategies], in Potocki, A. (ed.) Mechanizmy i obszary przeobrażeń organizacyjnych [The Mechanisms \& Areas of Organizational Tranformations], Warszawa: Difin, pp. 125-133. 
[5] Kozina, A. (2012) Planowanie negocjacji w przedsiębiorstwie [Negotiations Planning in a Company], Kraków: Wydawnictwo Uniwersytetu Ekonomicznego w Krakowie.

[6] Lewicki, R.J., Saunders, D.M. and Barry, B. (2010) Essentials of Negotiation, $5^{\text {th }}$ edition, New York: McGraw-Hill Publishing.

[7] Pearce, J.A. and Robinson, R.B. (2012) Strategic Management. Planning for Domestic \& Global Competition, $13^{\text {th }}$ edition, New York: McGraw-Hill Higher Education.

[8] Susskind, L.E. and Crump, L. (2008) Multiparty Negotiation, London: Sage Publications.

[9] Thompson, L. (2001) The Mind \& Heart of The Negotiator, $2^{\text {nd }}$ edition, New Jersey: Prentice Hall, Upper Saddle River.

[10] Watkins, M. and Passow S. (1996) 'Analyzing Linked Systems of Negotiations', Negotiation Journal, vol. 12, issue 4 (October), pp. 325-339. 